\title{
KOON TÍPUSÚ ANYAGMOZGATÓ RENDSZEREK MEGBÍZHATÓSÁGA
}

\author{
Madarász Kata \\ BSc hallgató, Miskolci Egyetem \\ Logisztikai Intézet \\ 3515 Miskolc, Miskolc-Egyetemváros, email: madesz.k@gmail.com \\ Bányai Tamás \\ egyetemi docens, Miskolci Egyetem \\ Logisztikai Intézet \\ 3515 Miskolc, Miskolc-Egyetemváros,email: alttamas@uni-miskolc.hu
}

\begin{abstract}
Absztrakt
A logisztikai és anyagáramlási rendszerek tervezésének számos szempontja van: költség, kapacitás kihasználtság, rugalmasság, átláthatóság, környezetterhelés. A megbizhatóság ezen tervezési szempontokra jelentös hatást tud gyakorolni. A logisztikai rendszerek és ellátási láncok tervezésében a megbizhatósági kérdések megválaszolásának egyre nagyobb szerep jut, hiszen nagy igény mutatkozik a beruházási és üzemeltetési költségek csökkentésére a rendszerek és folyamatok megbizhatóságának fokozása mellett. Jelen kutatómunka célja a koon (k-out-of-n) típusú anyagáramlási folyamatok megbizhatóságának vizsgálata. Bemutatásra kerül az egyes rendszerelemek megbizhatóságának rendszer-megbizhatóságra gyakorolt hatása, valamint egy esettanulmányon keresztül bemutatjuk, hogy anyagmozgató gépek megbizhatóságát is lehet, mint rendszer-megbizhatóságot kezelni gépelemek, mint rendszerek megbizhatóságaként.
\end{abstract}

Kulcsszavak: megbizhatóság, logisztika, anyagkezelés, tervezés, ellátási lánc

\begin{abstract}
The design of logistics and material handling systems includes a wide range of design aspects: costs, capacity utilization, flexibility, transparency, ecology. The reliability has a great impact on these design aspects. The reliability of logistics and supply chain solutions has become more and more importance. There is an increasing demand for reducing investment and operation costs while reliability of systems and processes must be improved. The presented research work involves the description of k-out-of-n types of material handling systems. The objective is to study and evaluate the effect of system elements on the reliability of material handling systems. Also, it has been established that material handling machines can be analyzed as systems of machines elements.
\end{abstract}

Keywords: reliability, logistics, material handling, design, supply chain

\section{Bevezetés}

A megbízhatóság a müszaki rendszerek és folyamatok szinte minden területén kiemelt fontosságú, hiszen az emberélet és az anyagi javak megóvása mellett gazdasági következményekkel is járhat egy nem megfelelő megbízhatósággal rendelkező eszköz, rendszer vagy folyamat. Jelen kutatómunka keretében az anyagmozgatási folyamatok egy speciális típusára, a „k-out-of- $n$ ” típusú rendszerekre (továbbiakban koon) fókuszálva mutatjuk be, hogy milyen hatással van az egyes rendszerelemek 
megbízhatósága egy anyagmozgatási folyamat megbízhatóságára. Azt érdemes már a kutatómunka elején leszögezni, hogy nem lehet cél a 100\%-os megbízhatóság elérése, hiszen egyrészt ennek múszaki akadálya vannak, másrészt nem minden esetben szükséges nagy megbízhatóság magas költségen történő biztosítása.

A termelési rendszerek komplexitásának növelése egyre nagyobb elvárásokat támaszt a kiberfizikai rendszereket felépítő technológiai és logisztikai objektumok megbízhatóságával szemben. A megbízhatóság fokozásának egyik eszköze az automatizált, robotizált megoldások alkalmazása, melyekkel nagymértékben fokozható a hagyományos, emberei közremüködéssel végzett tevékenységek megbízhatósága. Az egyre komplexebbé váló termékek egyre többfajta alkatrész, szerelvény és részegység beszerzését, gyártását és összeszerelését teszik szükségessé, ami egyre komplexebb ellátási láncok kialakulásához vezet. Ezen ellátási láncok egyik fontos jellemzője a kooperáció, mely előtérbe helyezi az olyan típusú ellátási láncok kialakítását, melyek alapvetően koon típusúak, azaz az ellátási lánc mindaddig müködőképes és alkalmas a termeléshez szükséges alapanyagigények kielégítésére, amíg az ellátási lánc $k$ eleméből $n$ elem működőképes, azaz alkalmas feladatának ellátására.

A megbízhatósági modellek alkalmazása a logisztika területén nem számít újnak, de jelentőségüket nagymértékben növelte a kiberfizikai rendszerek megjelenése [1]. Nem csupán a termelési rendszerekhez [2], hanem a szolgáltatási tevékenységekhez kapcsolódó logisztikai folyamatok megbízhatósága nagy jelentőséggel bír, különösen az egészségügyi, közbiztonsági és tủzvédelmi szolgáltatások esetében [3]. A megbízhatósági modellek nem csupán determinisztikus, hanem sztochasztikus környezetben is értelmezhetőek, bár modellezésük jelentősen nagyon kihívást jelent [4]. A Miskolci Egyetem Logisztikai Intézetében az anyagmozgatási és logisztikai rendszerek tervezésére vonatkozóan több évtizede folynak kutatások, melyek számos területet ölelnek át: hagyományos gyártórendszerek, virtuális vállalatok [5] és holonikus gyártás [6]. A negyedik ipari forradalom megjelenésével egyre inkább fókuszba kerülnek a minőségirányítás és minőségbiztosítás vonatkozásai, hiszen ezek szorosan összefüggnek a rendszerek és folyamatok megbízhatóságával [7]. Ezen kutatói mühely munkájához kapcsolódik jelen kutatómunka.

Jelen kutatómunka kitüzött célja a koon típusú anyagáramlási folyamatok megbízhatóságának vizsgálata és egy esettanulmányon keresztül annak bemutatása, hogy az egyes rendszerelemek megbízhatósága hogyan befolyásolja a teljes folyamat megbízhatóságát. Ezen cél elérése érdekében jelen cikk a következő fejezetekböl épül fel. A második fejezetben ismertetünk néhány megbízhatósági alapfogalmat, illetve azon megbízhatósági alapmodelleket, melyekből a koon típusú megbízhatósági modellek felépíthetőek. A harmadik fejezetben ismertetjük a koon típusú megbízhatósági alapmodelleket, illetve kísérletet teszünk arra, hogy valamilyen általános összefüggést találjunk az egyes analitikus megoldóképletek között, hiszen a szakirodalomban a koon típusú összetett rendszerek általában szimulációval kerülnek megoldásra. A negyedik fejezetben esettanulmányon keresztül mutatjuk be a koon típusú anyagmozgató rendszerek megbízhatósági számításait. Az ötödik fejezet a kutatómunka összefoglalását tartalmazza, magába foglalva a kutatómunka további lehetséges irányait.

\section{Megbízhatósági alapmodellek}

Az anyagmozgató gépek megbízhatósága az őket alkotó alkatrészek, az azok közötti kapcsolatok, illetve környezeti tényezők véletlenszerü eseményeinek alapján határozható meg, ezért leírásukra valószínűségi változókat célszerü alkalmazni. A valószínüségi változók számos tulajdonsága 
fogalmazható meg, melyek közül a sürüségfüggvény, az eloszlásfüggvény, a meghibásodási függvény, a meghibásodási függvény és a meghibásodási ráta fogalmát célszerü feleleveníteni az anyagmozgató gépek és rendszerek megbízhatóságának tárgyalása előtt $[8,9]$.

- Egy $\vartheta$ valószínúségi változó $F(t)$ eloszlásfüggvényén az $\vartheta \leq t$ esemény valószínüségét leíró függvényt értjük:

$$
F(t)=p(\vartheta<x)
$$

Az eloszlásfüggvényekre igaz, hogy értékük mindig egy $[0,1]$ intervallumba esik, azaz $0 \leq$ $F(t) \leq 1$.

- Egy $\vartheta$ valószínüségi változó $f(t)$ sürüségfüggvényén az $F(t)$ eloszlásfüggvény deriváltja az $[0,1]$ intervallumba, amennyiben az $F(t)$ eloszlásfüggvény ezen intervallumon differenciálható.

- A meghibásodási függvény annak a valószínüségét adja meg, hogy egy adott elem t időn belül biztosan meghibásodik. Ezt az élettartamot leíró eloszlásfüggvénnyel lehet megadni.

- A megbízhatósági függvény annak a valószínúségét adja meg, hogy egy adott elem $t$ időn belül biztosan nem hibásodik meg. A megbízhatósági függvény a meghibásodási függvény komplementereként definiálható.

- A meghibásodási ráta annak a valószínüségét adja meg, hogy egy adott $t$ ideig üzemelő elem meghibásodik. Meghatározása az alábbi módon végezhető el a valószínüségi változó sürüségfüggvényének és eloszlásfüggvényének segítségével:

$$
\lambda(t)=\frac{f(t)}{1-F(t)}=\frac{f(t)}{p(t)}
$$

Jelölje $p_{i}(t)$ annak a valószínűségét, hogy egy anyagmozgató gép $t$ időpontban müködik. Ekkor az anyagmozgató gépekből felépülő rendszer $t$ időpontban történő müködésének valószínüsége az egyes elemek müködési valószínűségeinek függvényeként határozható meg:

$$
p_{R}(t)=f\left(p_{1}(t), p_{2}(t) \ldots p_{i}(t) \ldots p_{n}(t)\right)
$$

Amennyiben egy anyagmozgató rendszer sorba kötött anyagmozgató gépekböl épül fel, akkor az anyagmozgató rendszer megbízhatósága az egyes megbízhatóságok produktumaként határozható meg:

$$
p_{R s}(t)=\prod_{i=1}^{n} p_{i}(t)
$$

Amennyiben a rendszerben található $m$ darab gép megbízhatósága megegyezik, azaz $\mathrm{p}_{i}(t)=p(t)$, akkor a rendszer megbízhatósága az (5) összefüggéssel határozható meg.

$$
p_{R s}(t)=p^{n}(t)
$$

Amennyiben egy anyagmozgató rendszer párhuzamosan müködő anyagmozgató gépekből épül fel, akkor az anyagmozgató rendszer megbízhatósága a (6) összefüggéssel határozható meg:

$$
p_{R p}(t)=1-\prod_{i=1}^{n}\left(1-p_{i}(t)\right)
$$




\section{KOON típusú anyagmozgató rendszerek megbízhatóságának elméleti alapjai}

\subsection{K-out-of-n típusú anyagmozgató rendszerek megbízhatósága}

Vannak olyan anyagmozgató rendszerek, amelyek esetében a rendszert addig tekintjük müködőképesnek, amíg $m$ darab eleméből legalább $k$ darab elem müködik. Az angol nyelvü szakirodalom [10] az ilyen típusú rendszereket koon rendszereknek nevezi ( $k$ out of $n)$. Az egy darab pótkerékkel rendelkező tricikli egy tipikus példa a 3oo4 típusú rendszerre, hiszen amíg 3 kerék jó a 4ből, addig a tricikli (a kerekek szempontjából) müködöképes. A továbbiakban nevezzük mi is az ilyen típusú rendszereket koon rendszereknek. Az loon megfelel a soros rendszernek, míg az noon megfelel a párhuzamos rendszernek.

Feltételezve, hogy a rendszert felépítő gépek megbízhatósága megegyezik, annak az esélye, hogy $n$ elemből pontosan $k$ elem müködik, a következö összefüggéssel határozható meg:

$$
p_{\text {koon }}(t)=\left(\begin{array}{l}
n \\
k
\end{array}\right) p^{k}(t)(1-p(t))^{n-k}
$$

Ebből következik, hogy annak a valószínűsége, hogy a rendszert felépítő $n$ elemből legalább $k$ elem működik, azaz a rendszer müködőképes, a következő összefüggéssel határozható meg:

$$
p_{\text {koon }}(t)=\sum_{j=k}^{n}\left(\begin{array}{l}
n \\
j
\end{array}\right) p^{j}(t)(1-p(t))^{n-j}
$$

Amennyiben a rendszer 3 elemet tartalmaz és már két elem müködése esetén müködőképesnek tekinthető a rendszer, a rendszer megbízhatósága az alábbi módon számítható:

$$
p_{2 o o 3}(t)=p_{1}(t) p_{2}(t)+p_{1}(t) p_{3}(t)+p_{2}(t) p_{3}(t)-2 p_{1}(t) p_{2}(t) p_{31}(t)
$$

Amennyibe a 2003 rendszerben az elemek megbízhatósága megegyezik, akkor felhasználva a (9) összefüggést a 2003 rendszer megbízhatósága az alábbi módon határozható meg:

$$
p_{2003}(t)=3 p^{2}(t)-2 p^{3}(t)
$$

A továbbiakban a koon megbízhatósági rendszerek néhány jellegzetes változatának analitikus megoldását állítjuk elő annak reményében, hogy sikerül valamilyen általános összefüggést találni az egyes analitikus megoldóképletek között.

- $\mathrm{n}=4, \mathrm{k}=2$ (2004)

$$
\begin{gathered}
p_{2004}=\sum_{j=2}^{4}\left(\begin{array}{l}
4 \\
2
\end{array}\right) p^{2}(1-p)^{4-2} \\
p_{2004}=\left(\begin{array}{l}
4 \\
2
\end{array}\right) p^{2}(1-p)^{2}+\left(\begin{array}{l}
4 \\
3
\end{array}\right) p^{3}(1-p)^{1}+\left(\begin{array}{l}
4 \\
4
\end{array}\right) p^{4} \\
p_{2004}=6 p^{2}-12 p^{3}+6 p^{4}+4 p^{3}-4 p^{4}+p^{4}=6 p^{2}-8 p^{3}+3 p^{4}
\end{gathered}
$$

- $\mathrm{n}=4, \mathrm{k}=3(3004)$

$$
p_{3004}=\sum_{j=3}^{4}\left(\begin{array}{l}
4 \\
3
\end{array}\right) p^{3}(1-p)^{4-3}
$$




$$
\begin{gathered}
p_{3004}=\left(\begin{array}{l}
4 \\
3
\end{array}\right) p^{3}(1-p)^{1}+\left(\begin{array}{l}
4 \\
4
\end{array}\right) p^{4} \\
p_{3004}=4 p^{3}-4 p^{4}+p^{4}=4 p^{3}-3 p^{4}
\end{gathered}
$$

$-\mathrm{n}=5, \mathrm{k}=2(2005)$

$$
\begin{gathered}
p_{2 o o 5}=\sum_{j=2}^{5}\left(\begin{array}{l}
5 \\
2
\end{array}\right) p^{2}(1-p)^{5-2} \\
p_{2 o o 5}=\left(\begin{array}{l}
5 \\
2
\end{array}\right) p^{2}(1-p)^{3}+\left(\begin{array}{l}
5 \\
3
\end{array}\right) p^{3}(1-p)^{2}+\left(\begin{array}{l}
5 \\
4
\end{array}\right) p^{4}(1-p)^{1}+\left(\begin{array}{l}
5 \\
5
\end{array}\right) p^{5} \\
p_{2 o o 5}=10 p^{2}\left(-3 p+3 p^{2}-p^{3}\right)+10 p^{3}\left(1-2 p+p^{2}\right)+5 p^{4}(1-p)+p^{5}= \\
=-20 p^{2}+45 p^{4}-4 p^{5}
\end{gathered}
$$

$-\mathrm{n}=5, \mathrm{k}=3(3 \mathrm{oo} 5)$

$$
\begin{gathered}
p_{3005}=\sum_{j=3}^{5}\left(\begin{array}{l}
5 \\
3
\end{array}\right) p^{3}(1-p)^{5-3} \\
p_{3005}=\left(\begin{array}{l}
5 \\
3
\end{array}\right) p^{3}(1-p)^{2}+\left(\begin{array}{l}
5 \\
4
\end{array}\right) p^{4}(1-p)^{1}+\left(\begin{array}{l}
5 \\
5
\end{array}\right) p^{5} \\
p_{3005}=10 p^{3}\left(1-2 p+p^{2}\right)+5 p^{4}(1-p)+p^{5}=10 p^{3}-15 p^{4}-4 p^{5}+10 p^{6} \\
-\quad \mathrm{n}=5, \mathrm{k}=4(4005) \\
p_{4005}=\sum_{j=4}^{5}\left(\begin{array}{l}
5 \\
4
\end{array}\right) p^{4}(1-p)^{5-4} \\
p_{4005}=\left(\begin{array}{l}
5 \\
4
\end{array}\right) p^{4}(1-p)^{1}+\left(\begin{array}{l}
5 \\
5
\end{array}\right) p^{5} \\
p_{40 o 5}=5 p^{4}(1-p)+p^{5}=5 p^{4}-4 p^{5}
\end{gathered}
$$

Megnézve ezeknek a rendszereknek a megbízhatóságait egyes esetekben láthatjuk, hogy nagy szabályszerüséget nem találunk köztük. Az összefüggés az esetek között mindösszesen annyi, hogy ha az $n$ értéke nem változik, a $k$ értéke pedig nő, akkor mindig az előző eseti egyenletből egy tag kiesik. Így az összevonás utáni végképletekben ez nem mutatkozik meg. Az előbb levezetett képletekkel szemléltetve:

$$
\begin{aligned}
p_{20 o 5} & =10 p^{2}\left(-3 p+3 p^{2}-p^{3}\right)+10 p^{3}\left(1-2 p+p^{2}\right)+5 p^{4}(1-p)+p^{5}= \\
& =-20 p^{2}+45 p^{4}-4 p^{5} \\
p_{30 o 5}= & 10 p^{3}\left(1-2 p+p^{2}\right)+5 p^{4}(1-p)+p^{5}=10 p^{3}-15 p^{4}-4 p^{5}+10 p^{6} \\
p_{4 o o 5} & =5 p^{4}(1-p)+p^{5}=5 p^{4}-4 p^{5}
\end{aligned}
$$




\section{Esettanulmányok}

\subsection{8 típusú anyagmozgató rendszer megbízhatósága}

Egy külszíni fejtésen a kifejtett érc szállítására nyolc szállítópálya áll rendelkezésre, melyek közül legalább hatnak kell müködőképesnek lennie ahhoz, hogy a kitermelt érc a kitermelés megszakítása nélkül elszállítható legyen. Tapasztalatok alapján az egyes szállítópályák megbízhatósága $80 \%$. A szállítópályák müködése egymástól független. Mennyi a valószínüsége, hogy a kitermelés zavarmentesen megvalósítható a vizsgálati időhorizonton belül?

$$
p_{6008}=\sum_{j=6}^{8}\left(\begin{array}{l}
8 \\
6
\end{array}\right) p^{6}(1-p)^{8-6}
$$

Kifejtve az összefüggést azt kapjuk, hogy:

$$
p_{6008}=\left(\begin{array}{l}
8 \\
6
\end{array}\right) p^{6}(1-p)^{2}+\left(\begin{array}{l}
8 \\
7
\end{array}\right) p^{7}(1-p)^{1}+\left(\begin{array}{l}
8 \\
8
\end{array}\right) p^{8}
$$

Felbontva a fenti összefüggést azt kapjuk, hogy:

$$
p_{R 6008}=28 p^{6}-48 p^{7}+21 p^{8}=0,79
$$

Tehát a rendszer eredő megbízhatósága 79\%, amennyiben 6 szállítópálya üzemképessége esetén az anyagmozgató rendszert müködöképesnek tekintjük.

A menedzsment részéröl elvárásként fogalmazódott meg, hogy az egyes szállítópályák megbízhatóságát a karbantartási tevékenység fokozásával olyan mértékben kell javítani, hogy a rendszer eredő megbízhatósága 95\% legyen.

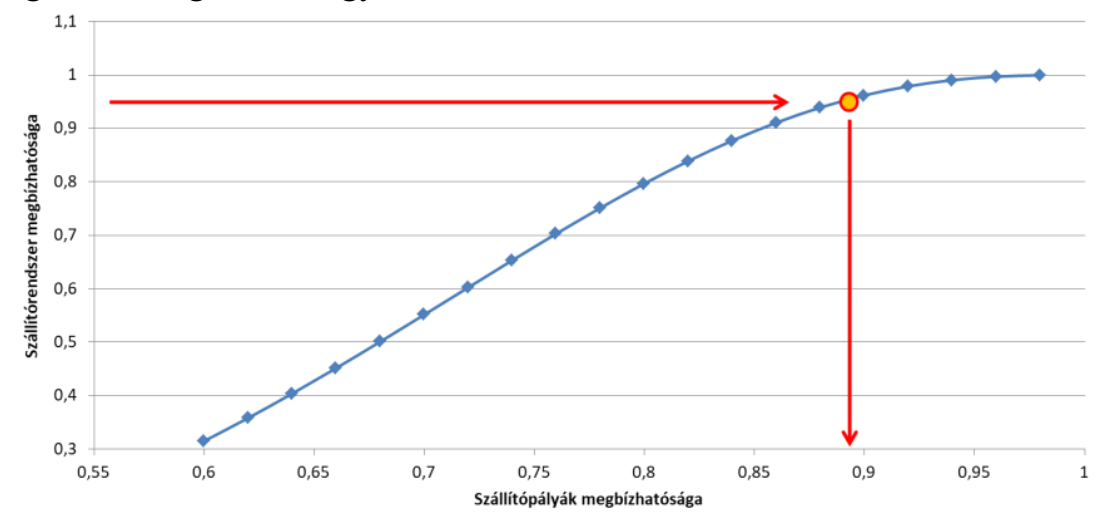

1. ábra 6008 szállitórendszer megbizhatósága az azonos megbizhatóságú szállitópályák megbizhatósági értékeinek függvényében

\subsection{4 típusú koon ellátási rendszer megbízhatósága}

Egy termelési folyamatban 4 beszállító alkalmas a gyártott termékekhez szükséges alkatérszek beszállítására, viszont a beszállítók által gyártott alkatrészek iránti nagy kereslet miatt a beszállítók megbízhatósága 77,5\%, ami azt jelenti, hogy ilyen arányban tudják elvállalni az érkező megrendelések határidőre történő beszállítását.

$$
p_{2004}=\sum_{j=2}^{4}\left(\begin{array}{l}
4 \\
2
\end{array}\right) p^{2}(1-p)^{4-2}
$$


Kifejtve az összefüggést azt kapjuk, hogy:

$$
p_{2 o 04}=\left(\begin{array}{l}
4 \\
2
\end{array}\right) p^{2}(1-p)^{2}+\left(\begin{array}{l}
4 \\
3
\end{array}\right) p^{3}(1-p)^{1}+\left(\begin{array}{l}
4 \\
4
\end{array}\right) p^{4}
$$

Felbontva a fenti összefüggést azt kapjuk, hogy:

$$
p_{2004}=6 p^{2}-8 p^{3}+3 p^{4}=0,96
$$

A beszállítói rendszer eredő megbízhatósága 96\%, amennyiben 2 beszállító rendelkezésre állása esetén a rendszert müködőképesnek tekintjük. Tehát annak az esélye, hogy a rendszer nem müködőképes $4 \%$.

\subsection{Anyagmozgató gép, mint rendszer megbízhatósága}

A megbízhatósági vizsgálatok nem csupán rendszerek, hanem gépek esetében is elvégezhetőek, és ezen esetekben a gépet is tekinthetjük rendszernek, hiszen a gép nem más, mint gépelemekből felépülő rendszer. Az alábbi példa ezt a megközelítést szemlélteti.

Egy automatizált áruosztályozó rendszerben hajtott görgőspályás anyagmozgatás folyik. A hajtott görgőspálya egyes görgőit általában 1500 óránként kell cserélni, viszont a görgők 8\%-a több mint 3000 órát is kibír. Határozzuk meg annak a valószínüségét, hogy egy görgő 2500 órát is kibír.

Feltételezve, hogy a görgök élettartama normál eloszlás szerinti, ahol 1500 óra a várható élettartam és a megbízhatósági függvény az alábbi formában írható fel:

$$
p(t>3000)=1-p\left(\frac{t-1500}{\sigma} \leq \frac{3000-1500}{\sigma}\right)=0,08
$$

Mivel

$$
\Theta\left(\frac{1500}{\sigma}\right)=0,92
$$

A standard normális eloszlású változók eloszlásfüggvényének táblázatából kiolvasható, hogy $\Theta(1,405) \approx 0,92$, amiböl következik, hogy

$$
\frac{1500}{\sigma}=1,405
$$

azaz a görgök élettartamának szórása: $\sigma=1068$ óra.

Az élettartam szórásértékének ismeretében meghatározható, hogy milyen valószínüséggel bír ki egy görgő 2500 órát:

$$
\begin{gathered}
p(t>2500)=1-p\left(\frac{t-1500}{1068} \leq \frac{2500-1500}{1068}\right), \\
p(t>2500) \approx 1-\Theta(0,936) \approx 0,1755,
\end{gathered}
$$

Tehát egy görgő $17,55 \%$ valószínüséggel bír ki 2500 órát.

\section{5. Összefoglalás}

Az anyagmozgatási rendszerek megbízhatósága a kiéleződő piaci versenyben egyre fontosabbá válik a termelési rendszerekben, hiszen a fokozódó vásárlói igények kielégítése csak nagy rendelkezésre- 
állással bíró rendszerekkel valósítható meg költséghatékonyan, ugyanakkor a nagyfokú megbízhatóság megvalósításának is komoly költségvonzata van. Jelen kutatómunka keretében azt vizsgáltuk, hogy a koon típusú anyagmozgató rendszerek megbízhatóságát hogyan lehet meghatározni. Esettanulmányokon keresztül mutattuk be a koon típusú anyagmozgató rendszerekben a rendszer megbízhatóságának függését az egyes rendszerelemek megbízhatóságától, illetve demonstráltuk azt, hogy az anyagmozgató gépeket gépelemek rendszerének tekintve rendszerként is vizsgálhatjuk. A kutatás további irányaként fogalmaztuk meg a koon típusú anyagmozgató rendszerek szimulációs vizsgálatát.

\section{Köszönetnyilvánítás}

A cikkben ismertetett kutatómunka az EFOP-3.6.1-16-2016-00011 jelü „Fiatalodó és Megújuló Egyetem - Innovatív Tudásváros - a Miskolci Egyetem intelligens szakosodást szolgáló intézményi fejlesztése" projekt részeként - a Széchenyi 2020 keretében - az Európai Unió támogatásával, az Európai Szociális Alap társfinanszírozásával valósul meg.

\section{Irodalomjegyzék}

[1] Zhang, Z.Y., Zhao, J.Y., Cui, J., Nie, H. Reliability analysis of logistics network of rail-sea intermodal transportation in Internet of Things environment. Journal of Coastal Research 2018, 83:823-827. https://doi.org/10.2112/SI83-135.1

[2] Skapinyecz, R.; Illés, B.; Bányai, Á. Logistic aspects of Industry 4.0. IOP Conference Series: Materials Science and Engineering 2018, 448:012014. https://doi.org/10.1088/1757899X/448/1/012014

[3] Wang, W., Huang, L., Liang, X.D. On the simulation-based reliability of complex emergency logistics networks in post-accident rescues. International Journal of Environmental Research and Public Health 2018, 79(1):79. https://doi.org/10.3390/ijerph15010079

[4] Lin, Y.K., Huang, C.F., Liao, Y.C. Reliability of a stochastic intermodal logistics network under spoilage and time considerations. Annals of Operations Research 2019, 277(1):95-118. https://doi.org/10.1007/s10479-017-2572-6

[5] Cser, L., Cselényi, J., Geiger, M., Mantyla, M., Korhonen, A.S. Logistics from IMS towards virtual factory. Journal of Materials Processing Technology 2000, 103(1):6-13. https://doi.org/10.1016/S0924-0136(00)00412-X

[6] Cselényi, J., Tóth, T. Some questions of logistics in the case of holonic production systems. Journal of Intelligent Manufacturing 1998, 9(2):113-118. https://doi.org/10.1023/A:1008859711052

[7] Tamás, P., Illés, B., Dobos, P., Skapinyecz, R. New Challenges for Quality Assurance of Manufacturing Processes in Industry 4.0, Solid State Phenomena 2017, 261:481-486. https://doi.org/10.4028/www.scientific.net/SSP.261.481

[8] Szántó, J. Karbantartásszervezés és ökonómiája. Forrás: https://www.tankonyvtar.hu/. Letöltve: 2019. augusztus 12.

[9] Pupos, T., Pintér, G. Döntéstámogató módszerek. Forrás: https://www.tankonyvtar.hu/. Letöltve: 2019. augusztus 12.

[10] Rausand, M.; Hoyland, A. System reliability theory: models, statistical methods and applications. John Wiley \& Sons. 2004. Hoboken, New Jersey. 